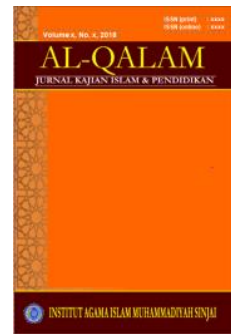

AL-QALAM

Jurnal Kajian Islam \& Pendidikan

Volume 07 No 022015

ISSN (print) : 1858-4152

ISSN (online) : 2715-5684

Homepage : http://journal.iaimsinjai.ac.id/index.php/al-qalam

\title{
PENDEKATAN DALAM PENDIDIKAN ISLAM
}

\author{
Oleh : Sardiyanah ${ }^{*}$
}

$* * *$

\begin{abstract}
Abstrak
Kehadiran agama secara fungsional dalam hal pendidikan, dapat dirasakan oleh penganutnya. Sebaliknya, tanpa mengetahui berbagai pendakatan tersebut, maka tidak mustahil nilai-nilai pendidikan agama, akan menjadi sulit dipahami oleh masyarakat. dalam tulisan ini, akan diuraikan definisi dan bentuk pendekatan yang dipakai dalam pendidikan Islam. Hasil pembahasan menunjukkan bahwa Pendekatan dalam pendidikan Islam adalah cara pandang atau paradigma yang dipakai dalam mengiterpretasikan nilai-nilai agama islam lewat pendidikan dengan tujuan untuk membentuk manusia seutuhnya yang beriman kepada Allah SWT. Di antara bentuk pendidikan dalam pendidikan Islam: 1) Rasional; 2) Emosional (Psikologis); 3) Holistic; 4) System; dan 5) Historis. Adapun Aspekaspek yang dapat mengabstraksikan pendekatan adalah: 1) Filosofis; 2) Epistemologis; dan 3) Paedagogis.
\end{abstract}

Kata Kunci: Pendidikan, Pendekatan, Islam, Abstraksi

\section{PENDAHULUAN}

$\mathbf{U}$

ntuk membangun teori Islam sebagai paradigma ilmu pendidikan, maka perlu ditemukan konsep pendidikan Islam yang ideal. Tugas ini adalah tanggung jawab moral setiap muslim pakar pendidikan. Dalam konteks ini, paradigma ilmu pendidikan Islam, mempunyai karakteristik yang berbeda dengan paradigma-paradigma pendidikan lainnya yang mendasari konsep pendidikan dewasa ini, khususnya di Indonesia, system pendidikan yang kita terapkan di sekola-sekolah merupakan bentuk adopsi sistemik dari system pendidikan barat sekuler.

Islam sebagai paradigma ilmu, dapat dirumuskan maksudnya sebagai penggunaan nilai-nilai islam dalam sudut pandang secara menyeluruh mengenai

${ }^{*}$ Dosen Tetap STAI Muhammadiyah Sinjai 


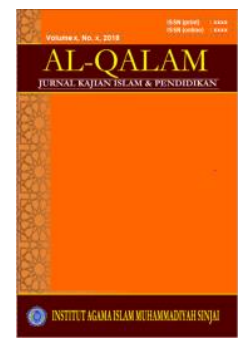

\section{AL-QALAM}

Jurnal Kajian Islam \& Pendidikan

Volume 07 No 022015

ISSN (print) : 1858-4152

ISSN (online) : 2715-5684

Homepage : http://journal.iaimsinjai.ac.id/index.php/al-qalam

persoalan-persoalan yang berkaitan dengan gejala-gejala pendidikan dalam rangka menyusun teori pendidikan. ${ }^{1}$

Dalam mewujudkan nilai-nilai Islam tersebut, perlu adanya adanya suatu konsep yang menerapkan tools (alat bantu) dalam memahami ilmu-ilmu pendidikan Islam. Tools tersebut merupakan sekumpulan pendekatan yang masing-masing dapat memberikan pemahaman yang dibutuhkan.

Hal demikian itu perlu didahulukan, karena melalui pendekatan tersebut, kehadiran agama secara fungsional dalam hal pendidikan, dapat dirasakan oleh penganutnya. Sebaliknya, tanpa mengetahui berbagai pendakatan tersebut, maka tidak mustahil nilai-nilai pendidikan agama, akan menjadi sulit dipahami oleh masyarakat, tidak fungsional, dan akhirnya masyarakat mencari pemecahan masalah kepada selain pendidikan agama. ${ }^{2}$

Dalam hubungan ini, pendidikan agama dapat diteliti dengan menggunakan berbagai paradigm pendekatan, realitas pendidikan keagamaan yang diungkapkan mempunyai nilai kebenaran sesuai dengan kerangka paradigmanya. Karena itu, tidak ada persoalan, apakah penelitian pendidikan Islam itu memakai pendekatan social legalistic atau filosofi.

Berdasarkan uraian tesebut di atas, maka dalam tulisan ini, akan diuraikan definisi dan bentuk pendekatan yang dipakai dalam pendidikan Islam.

\section{PENGERTIAN}

\section{Pendekatan}

Kata pendekatan berasal dari kata dasar "dekat" yang artinyatidak jauh, hampir, akrab, kemudian mendapat awalan dan ahiran sehingga menjadi pendekatan yang mengandung arti proses pembuatan,cara mendekati. Usaha dalam rangka aktivitas penelitian untuk mengadakan hubungan yang diteliti. Metode-metode untukmencapai suatu pengertian terhadap apa yang diteliti. ${ }^{3}$

Menurut istilah, Taufik Abdullah yang dikutip oleh Dr. Abuddin Nata memberikan interpretasi tentang pendekatan adalah cara pandang atau

\footnotetext{
${ }^{1}$ Ismail SM, Nurul Huda, Abdul Khalid (ed). Paradigma Pendidikan Islam (Cet. 1; Semarang: Fakultas Tarbiyah IAIN Walisongo Semarang, 2000), h. viii

${ }^{2}$ Lihat Abuddin Nata, Metodologi Studi Islam, (cet. III; Jakarta: PT Raja Geofindo Persada, 1999), h.28

${ }^{3}$ Departemen Pendidikan dan kebudayaan, Kanus Besar Bahasa Indonesia (Jakarta: Balai Pustaka, 1993), h.217-218
} 


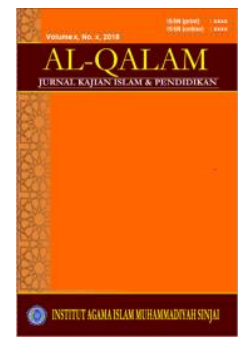

\section{AL-QALAM}

Jurnal Kajian Islam \& Pendidikan

Volume 07 No 022015

ISSN (print) : 1858-4152

ISSN (online) : 2715-5684

Homepage : http://journal.iaimsinjai.ac.id/index.php/al-qalam

paradigma yang terdapat dalam suatu bidang yang digunakan untuk memahami agama. ${ }^{4}$

Melihat dari persepsi tersebut diatas, maka istilah pendekatan merupakan suatu proses yang dilalui oleh seseorang untuk mendapatkan suatu hasil yang semaksimal mungkin. Pendekatan dapat diklasifikasikan kepada pendekatan yang subyektif dan obyektif. ${ }^{5}$

\section{Pendidikan.}

Istilah pendidikan berasal dari kata "didik" dengan memberikan awalan "pe" dan ahiran "kan" mengandung arti "perbuatan" (hal, cara, dan sebagainya) Istilah pendidikan ini semula berasal dari bahasa Yunani yaitu "paedagogis" yang berarti bimbingan yang diberikan kepada anak. Istilah ini kemudian diterjemahkan kedalam bahasa inggris dengan "education" yang berarti pengembangan atau bimbingan. Dalam bahasa Arabistilah ini sering diterjemahkan dengan "Tarbiyah" yang berarti pendidikan. ${ }^{6}$

Dari pengertian-pengertian di atas dapatlah dikatakan bahwa pendidikan islam (al-tarbiyahal-islamiyah) mempersiapkan manusia supaya hidup dengan sempurna dan bahagia, mencintai tanah air, tegap jasmaninya, sempurna budi pekertinya (akhlaknya), teratur pikirannya, halus perasaannya, mahir dalam pekerjaannya, halus tutur katanya baik dengan lisan atau tulisan. $^{7}$

Jadi, pendekatan dalam pendidikan Islam adalah cara pandang atau paradigm yang dipakai dalam menginterpretasikan nilai-nilai agama Islam lewat pendidikan dengan tujuan untuk membentuk manusia seutuhnya yang beriman kepada Allah SWT.

\section{MACAM-MACAM PENDEKATAN}

\section{Pendekatan Rasional}

Memahami Islam yang al-din tidak lagi cukup didekati dan dipahami hanya lewat pendekatan teologis normatif harus pula di dekatai dengan pendekatan-pendekatan aspectual, dimensional atau bahkan multi

\footnotetext{
${ }^{4}$ Abudin Nata, Op.Cit, h. 203

${ }^{5}$ Subyektif, apabila tiap-tiap subyek (pelaku) dalam mengemukakan sesuatu. Obyektif, pokok dari suatu masalah.

${ }^{6}$ Ramayulis. Ilmu Pendidikan Islam, (Cet. II; Jakarta: Kalam Mulia, 1998), h. 1

7 Ibid, h. 3-4
} 


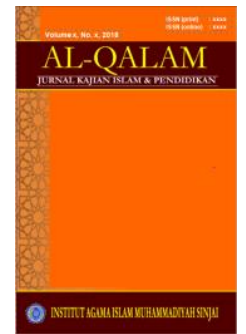

\section{AL-QALAM}

Jurnal Kajian Islam \& Pendidikan

Volume 07 No 022015

ISSN (print) : 1858-4152

ISSN (online) : 2715-5684

Homepage : http://journal.iaimsinjai.ac.id/index.php/al-qalam

dimensional approach. Keniscayaan tersebut membawa kepada imlikasi bahwa pendidikan islam sebagai institusi strategis untuk mengintensifkan suatu agama lewat pendekatan-pendekatan keilmuwan yang multi dan interdisipliner.

Salah satu pengembangan pendekatan dalam wil aksiologi dalam pendidikan islam adalah mengkonsepsikan kembali pendekatan, rasional. Pendekatan rasional dalam pendidikan islam biasanya lebih didominasi oleh warna atau nuansa sufistik dan cenderung asketis dan irrasional sehingga penghayatan yang dikembangkan lebih mengarah pada indoletinitasi atau takut akan ancaman. Sebagai alternative pengembangan pendekatan rasional memungkingkan kita menghadapi konsep-konsep etika yang bernuansa rasional.

Melalui konsep kewajiban immanual kant, pendekatan dalam pendidikan islam akan memberikan nuansa rasional dalam menangkap norma-norma kewajiban. Penghayatan terhadap kewajiban agama, jika didekati dengan paradikma rasional akan melahirkan pemahaman yang urut dari subtansi dan makna kewajiban tersebut sebagai anisal kewajiban melaksanakan "kebaikan" sebelumnya tidak saja atas dasar kologis [normatife, namaun juga dibenarkan dan diwajibkan oleh akal sehingga nilai "kebaikan" dari setiap aktifitas manusiah lebih dapat dipertanggung jawabkan dan dihayati sebagai suatu tindakan yang bermakna dalam kehidupan mereka. ${ }^{8}$

\section{Pendekatan emosional (psikologis)}

Psikologis atau ilmu jiwa adalah ilmu yang mempelajari jiwa seseorang melalui gejala perilaku yang dapat diamatinya menurut Zakiah Daradjat, ${ }^{9}$ bahwa perilaku seseorang yang Nampak lahirnyah terjadi karena dipengaruhi oleh keyakinan yang dianutnya. Seseorang ketika berjumpa saling mengucapkan salam, hormat kepada kedua orang tua, kepada Guru, menutup aurat, rela berkorban untuk kebenaran dan sebagainya merupakan gejala-gejala keagamaan yang dapat dijelaskan melalui ilmu jiwa agama. Ilmu jiwa agama sebagaimana dikemukakan Zakiah Daradjat tidak akan mempersoalkan benar tidaknya suatu agama yang dianut seseorang, melainkan yang yang dipentingkan adalah bagaimana keyakinan agama tersebut terlihat pengaruhnya dalam perilaku penganutnya.

Dalam ajaran agama banyak kita jumpai istilah-istilah yang menggambarkan sikap batin seseorang, misalnya, sikap beriman dan

${ }^{8}$ Ismail SM. Op.cit, h. 153-154

${ }^{9}$ Zakiah Darajat, Ilmu Jiwa Agama, (Jakarta: Bulan Bintang, 1987, cet. I), h. 76 


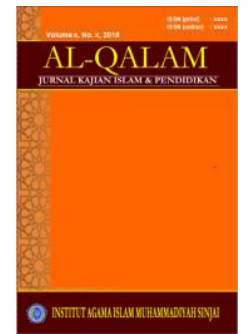

\section{AL-QALAM}

Jurnal Kajian Islam \& Pendidikan

Volume 07 No 022015

ISSN (print) : 1858-4152

ISSN (online) : 2715-5684

Homepage : http://journal.iaimsinjai.ac.id/index.php/al-qalam

bertakwa Kepada Allah, sebagai orang yang saleh, orang yang berbuat baik, orang yang jujur, dan sebagainya. Semua itu adalah gejala-gejala kejiwaan yang berkaitan dengan agama.

Dengan ilmu jiwa ini seseorang selain akan mengetahui tingkat keagamaan yang dihayati, dipahami dan diamalkan seseorang, juga dapat digunakan sebagai alat untuk memasukan agama kedalam jiwa seseorang sesuai dengan tingkatan usiahnya. Dengan ilmu ini agama akan menemukan cara yang tepat dan cocok untuk menanamkannya.

Kita misalnya dapat mengetahui pengaruh dari shalat, puasa, haji dan ibadah lainya dengan melalui ilmu jiwa. Dengan pengetahuan ini maka dapat disusun langkah-langkah baru yang lebih jiwa ini banyak digunakan sebagai alat untuk menjelaskan gejala atau sikap keagamaan seseorang. ${ }^{10}$

\section{Pendekatan Holistik.}

Dalam rangka meningkatkan keagamaan siswa, pendidikan agama kiranya perlu menggunakan pendekatan yang memungkingkan perkembangan keberagamaan siswa secara terpadu. Pendekatan holistic merupakan salah satu alternative yang sesuai untuk mengembangkan kurikulum pendidikan agama. Hal ini karena konsep dasar pendekatan ini sesuai dengan perinsip dasar dalam kehidupan beragama, yakni keterkaitan. ${ }^{11}$

Idealnya, pendekatan holistic dilaksanakan dengan cara menggabungkan dam memadukan sebanyak mungkin subyek pelajaran. Materi belajar yang disjikan kepada siswa tidak boleh difragmentasikan, menyebabkan pembelajaran kurang berarti bagi siswa. Hal ini karna konsep dasar holistic adalah keterkaitan yang salah satunya adalah keterkaitan antara mata pelajaran. Secara alami, mata pelajaran terkait satu sama lain sehingga keterpaduan dan keutuhan pemahaman siswa akan dapat dicapai secara efektif bila mata pelajaran tersebut secara bersama-sama dalam keterpaduan yang utuh.

Akan tetapi keterkaitan yang demikian ini dalam pendidikan agama di Indonesia nampaknya tidak mungkin karena keterbatasan kurikulum yang telah ditentukan oleh pemerintah yang memisahkan mata pelajaran yang dipelajari oleh siswa. Lebih-lebih pendidikan agama harus diasuh oleh guru spesialis sehingga menghubungkan dan mengkaitkan dengan mata pelajaran lain sudah belajar diluar otoritasnya.

${ }^{10}$ Lihat Abuddin Nata, Op.Cit, h. 50-51

${ }^{11}$ Lihat Ismail SM, Op. Cit, h. 125 


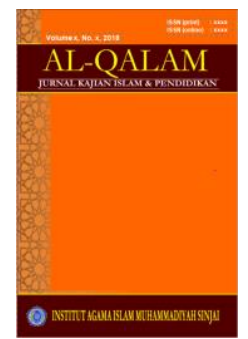

AL-QALAM

Jurnal Kajian Islam \& Pendidikan

Volume 07 No 022015

ISSN (print) : 1858-4152

ISSN (online) : 2715-5684

Homepage : http://journal.iaimsinjai.ac.id/index.php/al-qalam

Namun demikian, bukan berarti tertutup kemungkinan bagi guru agama untuk mengembangkan pembelajaran pendidikan agama dengan menggunakan pendekatan holistic. Guru agama masih mempunyai gerak meskipun terbatas.

Untuk mengembangkan pendekatan holistic karena perencanaan dan pelaksanaan pembelajaran sepenuhnya menjadi tanggung jawab dan wewenang mereka secara terbatas, guru dapat mengembangkan keterkaitan dan keterpaduan materi dalam pendidikan agam dan masyarakat. Implementasi pendekatan holistic dalam pendidikan agama akan memungkingkan siswa untuk mengembangkan pemahaman ajaran agama yang terintagrasi dan utuh, pada gilirannya, mereka dapat menyeimbangkan semua aspek kehidupan yang merupakan focus utama dari tujuan pendidikan agama islam. ${ }^{12}$

\section{Pendekatan Sistem.}

Teori sistemik dikembangkan oleh para ahli ilmuan muslim pada abad antara 8 sampai $13 \mathrm{M}$, di mana pada masa ini merupakan periode keemasan sejarah kebudayaan islam. Daya kreatifitas para ilmuan muslim pada prinsipnya bersumber dari informasi al-Qur'an yang memberikan petunjuk tentang system gerak benda-benda samawi dan kehidupan makhlukmakhluk termasuk dalam dari manusia sendiri secara biologis dan psikologis berjalan menurut mekanisme hukum-hukum Tuhan.

Pemikiran pemikiran teoritis berdasarkan pendekatan system di atas, mendapatkan inspirasi dari fenomena-fenomena gerakan yang sistematis secara makrokosmik dan dalam tubuh manusia sendiri secara mikrokosmik. Semua fenomena itu dipelajari dari dalam kandungan ayat-ayat kitab suci al-Qur'an.

Dalam kehidupan jasmaniah dan rohaniyah manusia juga Tuhan telah pula memberikan suatu system bekerjanya organ-organ yang teratur dan berjalan koordinatif antara suatu organ dengan organ lain sebagai suatu kesatuan yang utuh. Kondisi yang bersifat sistematik dan mekanistik itu merupakan sunnatullah (hokum tetap dari Allah). Untuk melangsungkan, menumbuhkan dan mengembangkan kehidupan manusia sebagai hamba Allah yang paling muliah dan paling baik struktur kejadianya di antara makhluk-makhluk lainnya.

${ }^{12}$ Lihat Ismail SM. Op. Cit, h. 132-133 


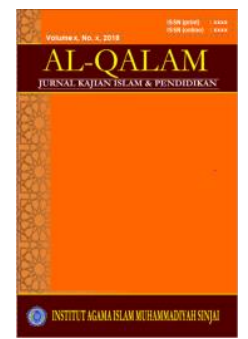

AL-QALAM

Jurnal Kajian Islam \& Pendidikan

Volume 07 No 022015

ISSN (print) : 1858-4152

ISSN (online) : 2715-5684

Homepage : http://journal.iaimsinjai.ac.id/index.php/al-qalam

Dilihat dari sistemik, kehidupan manusia secara jasmaniyah dan rohaniyah (psychis) jelas menunjukan bahwa pertumbuhan dan perkembangan hidupnya berjalan dalam suatu proses secara konsisten dan kontinuun (berkesinambungan) menunjukan kearah titik optimal dari kemampuan pertumbuahn dan perkembangan.

Dengan mengimitasi (mencontoh) system mekanisme bekerjanya alam (makro-kosmos) dan tubuh manusia sendiri, para ilmuwan, khususnya di bidang pendidikan, dapat menciptakan mesin-mesin, peralatan-peralatan perangkat lunak (software) dan keras (hardware), bahkan pada system persenjataan modern sekalipun.

Watak ilmu pendidikan islam adalah sistematik dan konsistem menuju arah tujuan yang hendak dicapai. Untuk itu, maka pendidikan islam memerlukan pemikiran sistemik dan mengarahkan prosesnya dalam systemsistem yang aspiratif terhadap kebutuhan umatnya. Bila tidak demikian, akan timbul gangguan dan hambatan-hambatan teknis operasional yang dapat menghilangkan orientasinya yang benar.

Semakin banyak gangguan yang timbul dalam suatu system, maka semakin besar pula daya perusak yang mengancam mekanisme system alam semesta, system kehidupan social dan system kehidupan individu (dilihat dari segi biologis). ${ }^{13}$

\section{Pendekatan Historis}

Analisis pendidikan islam dilihat dari latar belakang histories, berarti menempatkan sasaran analisa pada fakta-fakta sejarah umat islam berawal dari Nabi Muhammad diangkat menjadi Rasulullah saw.

Firman-firman Allah dalam kitab suci al-Qur'an yang mengandung nilai histories, tersirat di dalamnya nilai-nilai paedagosis yang merentang ke arah pembentukan kepribadian yang beriaman hanya kepada Allah yang maha Esa, mentauhidkan kepercayaan manusia kapada kekuasaan yang maha Esa yang baersifat mutlak, tak ada tandingan-Nya dalam alam semesta.

Analisis yang berdasarkan pendekatan histories membatasi studi pada ruangan lingkup pemikiran tentang proses dan nilai-nilai perkembangan sasaran analisis, dari sudut pandangan sejarah.

${ }^{13}$ Prof. H. M. Arifin, M.Ed., Ilmu Pendidikan Islam, (cet. V; Jakarta: PT, Bumi Aksara, 2000), h. 136-137 


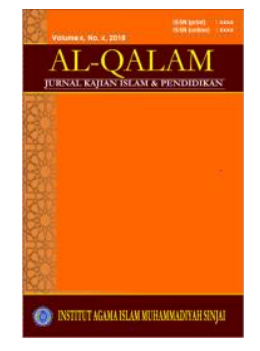

\section{AL-QALAM}

Jurnal Kajian Islam \& Pendidikan

Volume 07 No 022015

ISSN (print) : 1858-4152

ISSN (online) : 2715-5684

Homepage : http://journal.iaimsinjai.ac.id/index.php/al-qalam

Al-Qur'an adalah kitab suci wahyu Allah yang hampir $2 / 3$ isinya menjanjikan peristiwa-peristiwa sejarah baik yang menyangkut kehidupan bangsa, para Rasul, maupun tokoh-tokoh penting yang menciptakan sejarah.

Berbagai pandangan dari ulama dan ilmuwan islam tentang factor histories untuk menganalisa pendidikan islam menunjukkanbahwa pada prinsipnya pendidikan islam berproses pada 4 aspek:

a. Ideal, proses mencapai tujuan pendidikan sesuai dengan cita-cita ajaran islam dapat berlangsung dengan lancer bila berprinsip pada konsistensi dan kesinambungan dalam suatu system kemasyarakatan yang teratur rapi.

b. Institusional, tujuan atau cita-cita itu akan lebih mudah dicapai melalui proses kependidikan jika ditransformasikan melalui institusi kependidikan, Karena institusi menjadi wadah pengorganisasian dan pelaksanaan program untuk mencapai tujuan pendidikan.

c. Struktur, dengan struktur (bentuk) kelembagaan, kependidikan yang berjenjang (bertingkat), tujuan pendidikan islam dicapai secara bertahap sesuai tingkat-tingkat perkembangan manusia didik.

d. Materiil, tujuan akhir dan sementara pendidikan islam menentukan corak pelajaran, yang baru dapat nefektif dan efisien, jika diajarkan dengan system dan metode yang tepat guna sesuai dengan karakteristikdari idealitas nilai-nilaiyang terkandung dalam tujuan. ${ }^{14}$

\section{ASPEK-ASPEK YANG MENGABSTRAKSIKAN PENDEKATAN}

Setiap manusia memiliki kemampuan psikologis yang dapat dikembangkan melalui proses kependidikan ke arah pengembangannya yang optimal. Untuk aspek pendidikan islam secara teoritis dapat dibentuk sesuai beberapa aspek pendekatan sebagai berikut $^{15}$ :

1. Aspek filosofis : manusia selaku manusia didik hamba Tuhan telah diberi kemampuan dasar yang disebut fitrah yang bersifat dinamis dan berkecendrungansocial-religius dalam struktur psiko-fisk patuh dan menyerahkan diri kepada Maha Penciptanya secara total pada tingkatperkembangannya yang optimal.

\footnotetext{
${ }^{14}$ Ibid. h. 160-162.

${ }^{15}$ Lihat Ibid, h. 113-114
} 


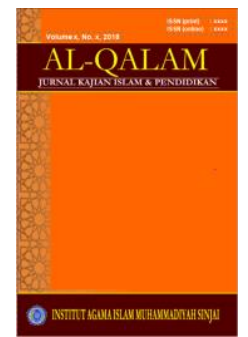

\section{AL-QALAM}

Jurnal Kajian Islam \& Pendidikan

Volume 07 No 022015

ISSN (print) : 1858-4152

ISSN (online) : 2715-5684

Homepage : http://journal.iaimsinjai.ac.id/index.php/al-qalam

2. Aspek epistemologis, manusia diberi kemampuan dasar untuk berilmu pengetahuan dan beriman kepada Maha Penciptanya sesuai dengan kemampuan derajat kemanusiaannya yang menjadi shibgah (bentuk atau pola dasar) keislamannya yang member corak kemuliaan derajatnya, melebihi yang lain.

3. Aspek paedagogis, manusia adalah mahluk belajar sepanjang hayat melalui proses yang didasari dengan nilai-nilai islami. Proses belajar yang islami adalah berlangsung secara dialogis kepada tuntutan Tuhannya dan kepada Tuntutan perubahan sosialnya, sehingga berkecendrunganke arah pola hidup harmonis (seimbang)antara kepentingan hidup duniawa dan ukhrawi, sejalan dengan tugas pokoknya sebagai "khalifah" di atas bumi.

\section{PENUTUP}

Dari uraian tersebut diatas dapatlah disimpulkan dalam ahir pembahasan ini sebagai berikut:

1. Pendekatan dalam pendidikan Islam adalah cara pandang atau paradigm yang dipakai dalam mengiterpretasikan nilai-nilai agama islam lewat pendidikan dengan tujuan untuk membentuk manusia seutuhnya yang beriman kepada Allah SWT.

2. Macam-macam pendekatan dalam pendidikan Islam adalah :
a. Pendekatan Rasional
b. Pendekatan emosional (psikologis)
c. Pendekatan holistic
d. Pendekatan system
e. Pendekatan historis

3. Aspek-aspek yang dapat mengabstraksikan pendekatan adalah:
a. Aspek filosofis
b. Aspek epistemologis
c. Aspek paedagogis 


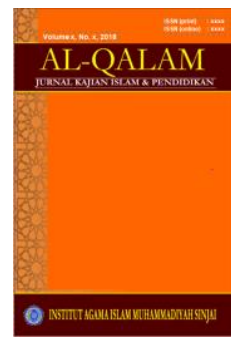

AL-QALAM

Jurnal Kajian Islam \& Pendidikan

Volume 07 No 022015

ISSN (print) : 1858-4152

ISSN (online) : 2715-5684

Homepage : http://journal.iaimsinjai.ac.id/index.php/al-qalam

\section{DAFTAR PUSTAKA}

Arifin, H.M. Prof, M.Ed., Ilmu Pendidikan Islam. Cetakan V; Jakarta: PT. Bumi Aksara, 2000.

Departemen Pendidikan dan kebudayaan. Kamus Besar Bahasa Indonesia. Jakarta: Balai Pustaka, 1993.

Darajat, Zakiah. Ilmu Jiwa Agama. Cet. I; Jakarta: Bulan Bintang, 1997.

Nata, Abuddin, Metodologi Studi Islam. Cet. III; Jakarta: PT. Raja Grafindo Persada, 1999.

Nurul Huda, Ismail SM, Abdul Khalid (ed). Paradigma Pendidikan Islam. Cet. I; Semarang: Fakultas Tarbiyah IAIN Walisongo, 2000.

Ramayulis. Ilmu Pendidikan Islam. Cet. II; Jakarta: Kalam Mulia, 1998. 